(10.21704/pja.v4i3.1645

http://revistas.lamolina.edu.pe/index.php/jpagronomy/index

(C) The authors. Published by Universidad Nacional Agraria La Molina

\title{
Prodiplosis longifila Gagné (Diptera: Cecidomyiidae) in asparagus (Asparagus officinalis) crop in Chavimochic Irrigation Project
}

\section{Prodiplosis longifila Gagné (Diptera: Cecidomyiidae) en el cultivo de espárrago (Asparagus officinalis) en el Proyecto de irrigación de Chavimochic}

\author{
Jorge Ramón Castillo Valiente ${ }^{1 *}$; Susana Patricia Rodríguez Quispe ${ }^{2}$; Walter Eduardo Apaza Tapia ${ }^{3}$; Alberto Marcial \\ Julca-Otiniano4; Manuel Antonio Canto Saenz ${ }^{5}$; Teresa Rosales Sanchez \\ *Corresponding author: joracava@1amolina.edu.pe
}

https://orcid.org/0000-0003-3561-2253

\begin{abstract}
The present study was conducted in the fields of the Chavimochic irrigation, located in La Libertad Region-Peru. Prodiplosis longifila Gagné (Diptera Cecidomyiidae) is considered the key pest of asparagus and other vegetables cultivation. This study aimed to characterize the presence of this insect pest in asparagus crop under drip irrigation conditions, in order to find the best alternatives for its control. The cultivar most planted in the Chavimochic Irrigation is cultivar UC 157 and that the meteorological conditions of the area are optimal for the production of asparagus; but also for the establishment and reproduction of the insect. The morphology of asparagus is favorable for reproduction of the insect, from larva to adult, since it frequently bracts and flowers at larval stage and establishs itself at the adult stage; at the base of the plant. All experiments conducted, had at least three repetitions and the results are given on average. The insect can have many hosts and an average biological cycle of 11 days, with the highest populations in the months of May and November. Throughout the day; the adult populations are very active from $10 \mathrm{pm}$ to $4 \mathrm{am}$. The drip irrigation system provides better conditions for the establishment of the insect and its reproduction in the fields, as well as the design of double row sowing so water management becomes an important factor for managing its populations. From the 100\% puparium that fell to the ground, only $37.95 \%$ emerged as adults. The percentage of damaged stems per linear meter can be 70.46 and healthy stems 29.54 . The number of larvae per shoot can be from 68 to 489 while number of larvae per male flower can be from 2 to 7 individuals. There is a relationship between flowering and the number or pre-pupae fallen to the ground, but as the crop develops, the adult's number decrease, but nevertheless is still aggressive and permanent.
\end{abstract}

Key words: Prodiplosis, Asparagus, Chavimochic

\section{Resumen}

El presente trabajo se desarrolló en los campos de la irrigación de Chavimochic, ubicada en la Región La libertadPerú. Prodiplosis longifila Gagné (Diptera Cecidomyiidae) es considerada plaga clave del cultivo de esparrago y de otras hortalizas. El objetivo del presente trabajo fue determinar el comportamiento del insecto a nivel de campo, en el cultivo de espárrago, bajo condiciones de riego por goteo, para buscar las mejores alternativas de su control. El cultivar mayormente sembrado en la Irrigación Chavimochic es el cultivar UC 157 y que las condiciones meteorológicas de la zona son óptimas para la producción de espárrago; pero también para el establecimiento y reproducción del insecto. La morfología del espárrago es favorable para la reproducción del insecto, desde larva hasta adulto, ya que puede frecuentar brácteas y flores al estado larval y establecerse al estado adulto, en la base de la planta. El insecto tiene muchos hospederos y un ciclo biológico promedio de 11 días, siendo los meses de mayo y noviembre donde desarrolla las más altas poblaciones. A lo largo del día se determinó que las poblaciones de adultos son muy activas desde las 10

Cite this article:
Castillo, J., Rodríguez, S., Apaza-Tapia, W., Julca-Otiniano, A., Canto, M. \& Rosales, T. (2020). Prodiplosis longifila
Gagné (Diptera: Cecidomyiidae) in asparagus (Asparagus officinalis) crop in Chavimochic Irrigation Project. Peruvian
Journal of Agronomy, 4(3), 75-81. http://dx.doi.org/10.21704/pja.v4i3.1645

\footnotetext{
${ }^{1}$ Universidad Nacional Agraria La Molina. Docente. Lima, Perú. joracava@lamolina.edu.pe

${ }^{2}$ Universidad Nacional Agraria La Molina. Docente. Lima, Perú. srodriguez@lamolina.edu.pe

${ }^{3}$ Universidad Nacional Agraria La Molina. Docente. Lima, Perú. wapaza@lamolina.edu.pe

${ }^{4}$ Universidad Nacional Agraria La Molina. Docente. Lima, Perú. ajo@lamolina.edu.pe

${ }^{5}$ Universidad Nacional Agraria La Molina. Docente. Lima, Perú. mcanto@lamolina.edu.pe

${ }^{6}$ Junta de usuarios de riego presurizado JURP. La Libertad. Perú. t.rosales@jriegopresurizado.org.pe
} 
p.m. hasta las 4 a.m. El número de larvas por turión puede ser de 68 hasta 489 y el número de lavas por flor masculina de 2 a 7 individuos. El porcentaje de tallos dañados por metro lineal pueden ser del 70.46 y de tallos sanos del 29.54. El Sistema de riego por goteo provee mejores condiciones para su establecimiento y reproducción en los campos, así como el diseño de siembra a doble hilera. El Sistema de riego por goteo provee mejores condiciones para su establecimiento y reproducción, así como el diseño de siembra a doble hilera, por lo que el manejo del agua se convierte en un factor importante para el manejo de sus poblaciones.

Palabras claves: Prodiplosis, Esparrago, Chavimochic

\section{Introduction}

The Chavimochic Irrigation Project is located in an arid ecosystem where an export agriculture has been established with a drip irrigation system, in the region of La Libertad, Northern Peru. In this region asparagus crop reached its maximum planted area in 2008 with 11,000 ha planted (Gobierno Regional La Libertad, 2010). UC157 $\mathrm{F} 1$ is the predominant cultivar, with approximately $90 \%$ of the asparagus cultivated area being a monoculture, thus causing the presence of many pests (Cisneros, 1995) (Figure 1).

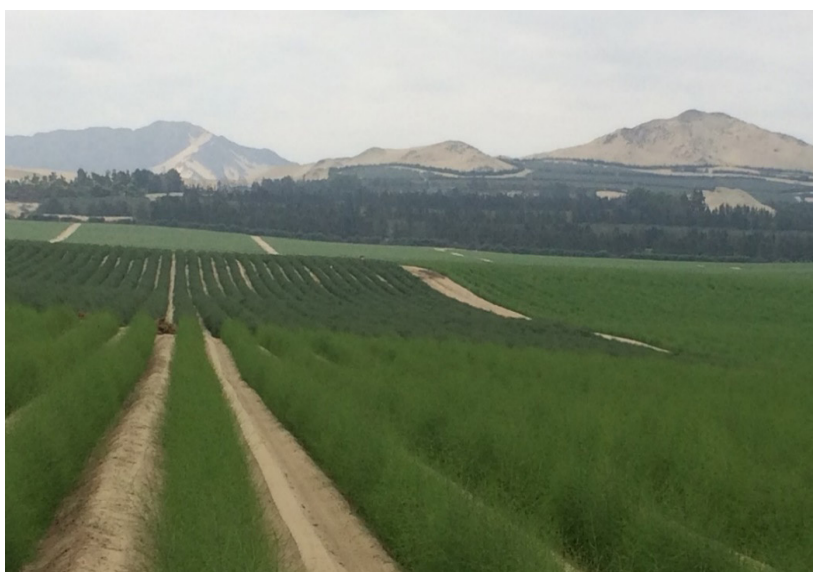

Figure 1. Asparagus plantation in the Chavimochic Irrigation Project.

Prodiplosis longifila Gagné is considered among the main entomological problems in the Chavimochic Irrigation Project (Sánchez \& Apaza, 2000), as a result of their damages to asparagus crop, as well as other crops in the area. Nine species of the Prodiplosis genus are recognized worldwide: P. platani Gagné, P. myricae (Beutenmüller), P. vaccini (Felt), P. citrulli (Felt), P. floricola (Felt), $P$. morrisis Gagné, $P$. violicola (Coquillett), $P$. falcata Gagné, and $P$. longifila Gagné. The last among the list has been reported for Peru (Gagné, 1986).

The aggressiveness of $P$. longifila is related to its multivoltine nature, that is, it produces many generations per year and has a wide range of hosts. The hosts reported for the United States are "lime" (Citrus aurentifolia) and "wild cotton" (Gossypium spp.). For Colombia and Peru this insect pest has been reported for tomatoes, potatoes, and alfalfa, among other crops (Peña et al., 1989). Chenopodium ambrosoides, Medicago sativa, Solanum spp., Phaseolus spp., and Ricinus comunis are hosts reported for Peru (Gagné, 1986).
At present, this insect has been documented as a pest of Asparagus offinialis, Tagetes spp., Allium spp., Persea spp., Cynara scolyumus, Capsicum spp., Cucumis spp., Citrullus spp. and Brassica oleraceae among other most important crops. Among weed hosts, we can find Chenopodium murale, Amaranthus spp. and Nicandria physalodes.

In asparagus crops, this pest generates many populations during most of its phenology, causing great infestations that can have negative consequences in production of the crop and neighboring ones.

This study aimed to characterize the presence of this insect pest in asparagus crop in Chavimochic Irrigation Project and analyze its behavior in order to understand why it has become a key pest of asparagus and other vegetables.

\section{Materials and methods}

We began the study by reviewing the information provided by "Crop Protection Committee of the Asociación de Agricultores Agroexportadores Propietarios de Terrenos de Chavimochic - APTCH" (Association of Agricultural Exporters and Owners of land of Chavimochic Crop Protection Committee) and "Junta de Usuarios de Riego Presurizado del Distrito de Riego Moche Virú Chao" (JURP.) (Pressurized Irrigation Users Board).

Field observations, interviews of field consultant (entomologists), agronomists, and field technicians related to pest management of different agro-industrial companies engaged in asparagus production were conducted.

Most of the information collected consisted of results from field experiments conducted with APTCH Crop Protection Committee and pest management technicians from different agro-industrial companies. In all of experiments carried out in the field, at least, three repetitions were made and the results are given on average.

\section{Results and discussions}

Due to the climatic conditions of Peru, especially in the northern zone, the asparagus crop is able to grow and produce twice a year, thus designing two growing season, one in summer autumn and another in winter - spring. The winter - spring season generally has the best yields, 
since it occurs in the Mediterranean area, which is the place of origin of the asparagus plant, given that in this season, the crop has the necessary requirements to transfer photosynthates, (such as fructooligosaccharides), from the aerial to root part (Benson, 1980). This optimal condition enables asparagus crops to produce all year round, thus implying that the plant is always active and, as such, produces sprouts continuously in different fields. Therefore, pests such as Prodiplosis longifila or others can damage soft asparagus tissues, generating several populations up to millions of insects per season.

During crop management, six (female plants) or four (male plants) developmental stages are considered: spear emergence, lateral shoot growth, phylloclades appearance, flowering, fruit development (only in female plants) and fruit maturation (only in female plants). In general, shoots are generated twice per growing season, either in summer or winter (Figure 2).

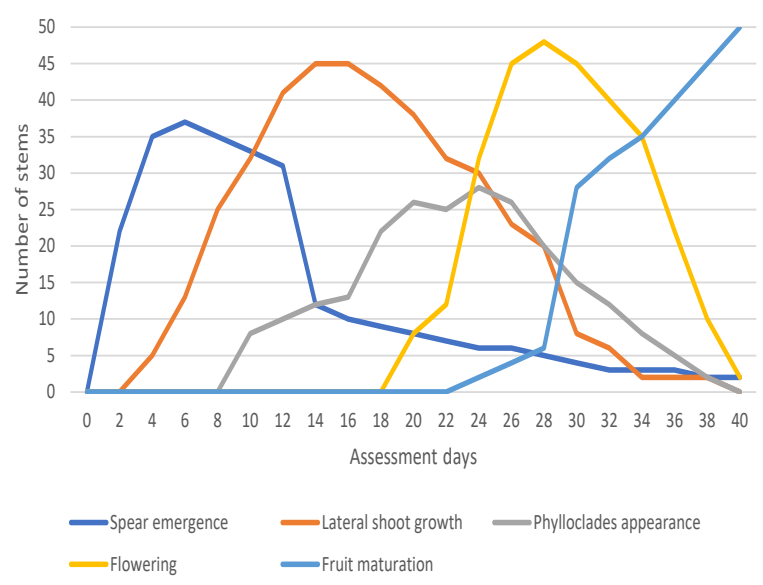

Figure 2. Asparagus growth stages during the first growing season in the Chavimochic Irrigation Project.

Of the six stages that can be controlled with great efforts the first three are most susceptible to insect damages; however, in flowering stages, the populations of the insect are so high the extent that it is impossible to control the damages caused by the insect (Castillo, 2006).

The insect damages are related to morphology of the asparagus plant, whose large amount of foliage helps the insect, at adult stage, to look for shelter in basal part of the plant, initially ovipositing in the emergent spears and later in flowers, thus generating large larvae populations that will later turn into adults. These populations can be recycled in the same field, since another generation can be obtained from new young shoots; however, those populations can be a source of adult infestation to neighboring fields.

From experiments conducted in the Chavimochic Irrigation Project, the biological cycle of $P$. longifila Gagné was determined to be 16 days under field conditions, between the months of May and June 2014 in first sprouting fields under $21.6^{\circ} \mathrm{C}, 82.07 \% \mathrm{HR}$. environmental conditions. (Table 1), which coincides with data obtained by Rodríguez (1992), in which 17.54 days, was determined under spring conditions and 12.71 determined under summer conditions in tomato crop.

Table 1. Duration of the biological cycle of Prodiplosis longifila Gagné, under field conditions in the asparagus crop in the Chavimochic Irrigation Project. 2014.

\begin{tabular}{cccc} 
& \multicolumn{3}{c}{ Duration in days } \\
\cline { 2 - 4 } STAGE & Minimum & Maximum & Average \\
\hline Egg & 1.5 & 1.8 & 1.6 \\
Larvae & 4.3 & 5.2 & 4.7 \\
Pre-pupae & 9.2 & 11.2 & 10.2 \\
Development cycle & & & \\
Male & 15.1 & 17.2 & 16.4 \\
Female & 15.4 & 17.7 & 16.7 \\
\hline
\end{tabular}

According to pest management specialists of the Chavimochic area, temperature is a key factor in the presence of $P$. longifila Gagné, among the environmental factors. Results of field evaluations along the Peruvian coast show that zones with temperatures above $30^{\circ} \mathrm{C}$ and below $11^{\circ} \mathrm{C}$, as well as those where day/night differential temperatures are greater than $10^{\circ} \mathrm{C}$, are not adequate for propagation of the pest.

According to the studies conducted with this insect by Valarezo et al. (2003) in tomato crop under Ecuadorian conditions, it was found that when there was an increase in temperature $\left(23.13\right.$ to $\left.27.92^{\circ} \mathrm{C}\right)$, relative humidity $(71.19$ to $86.47 \%$ ) and precipitation $(0.16$ to $108.5 \mathrm{~mm}$.), the population of this insect decreased, inferring that these abiotic factors have a direct effect on the populations. In Colombia, Hernández (2014) characterized the damage and distribution of the pest in "Tahiti" lemons and solanaceous crops, finding Prodiplosis in an altitude between 739 and 2168 masl, with temperatures between $22^{\circ} \mathrm{C}$ and $38.7^{\circ} \mathrm{C}$ and relative humidity levels between 37 $\%$ and $80 \%$. Velasco (2015), conducted a molecular study on Prodiplosis longifla populations based on geographic altitude distribution, and found that there is no population differentiation, since no groups were attributable to high or low regions, indicating that a population can maintain gene flow despite environmental variation, which partially explains its wide geographic distribution.

By observations of the author, along the Peruvian coast, this insect pest is distributed along the coast, precisely between the regions of Lambayeque and Ica. Currently, there are reports about the presence this insect in the region of Piura, but with different behavior; however, as reported in the aforementioned studies, this insect may likely colonize other areas.

In a study regarding population dynamics of the insect under light stimulation that was reported by APTCH plant health committee, it was found that the highest activity of Prodiplosis longifila Gagné adult was between $10 \mathrm{pm}$ and 4 am of the next day (Figure 3). 


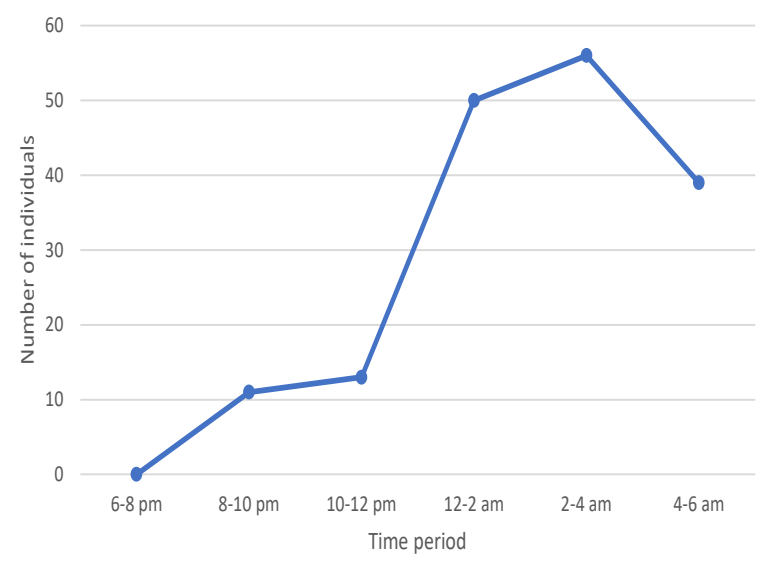

Figure 3. Number of Prodiplosis longifila Gagné adults captured per night in $100 \mathrm{~cm}^{2}$ light traps with a sticky surface panel. (2014).

Based on population dynamics studies conducted in the irrigation project, two months were recognized when the insect increases its population and reaches its highest population throughout the year: May and November (Figure 4).

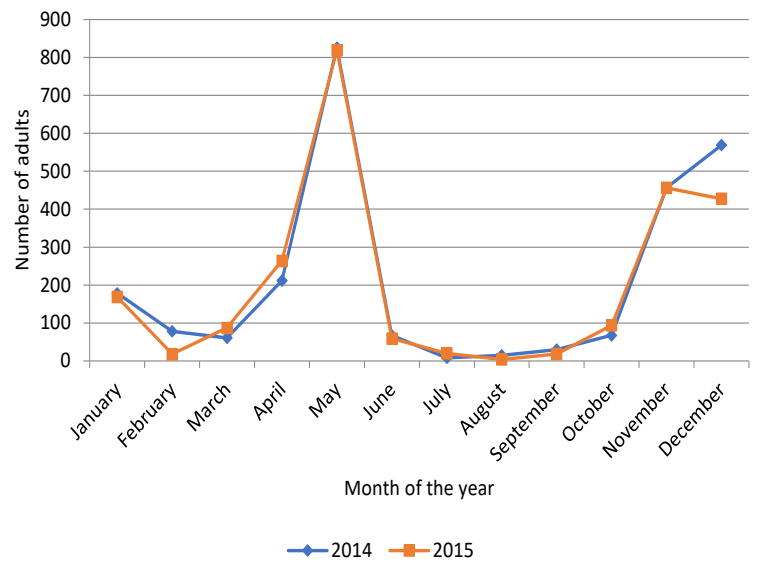

Figure 4. Number of Prodiplosis longfila Gagné adults in sticky surface panel traps throughout the year (2014 and 2015).

Drip irrigation system in asparagus has been applied since 1987; however, its massive implementation started at the beginning of year 2000 (Instituto Peruano del espárrago y hortalizas [IPEH], 2013). This irrigation system optimizes the use of water and fertilizer, and maybe of benefit to the adult insect, which prefers soil surfaces of constantly humid and protected areas

The moistened soil folloging the drippers provides humid conditions for the pupae to survive and grow to the adult stage. Based on data obtained from observations and field experiments conducted by entomologist of the Crop Protection Committee, through collection of preprepuae and emerged adults in containers, it was found that from the highest peak of infestation of $100 \%$ puparium that fell to the ground, only $37.95 \%$ emerged as adults (Figure 5). However, the population generated per hectare in this proportion is still high enough to produce a heavy infestation in the asparagus crop.

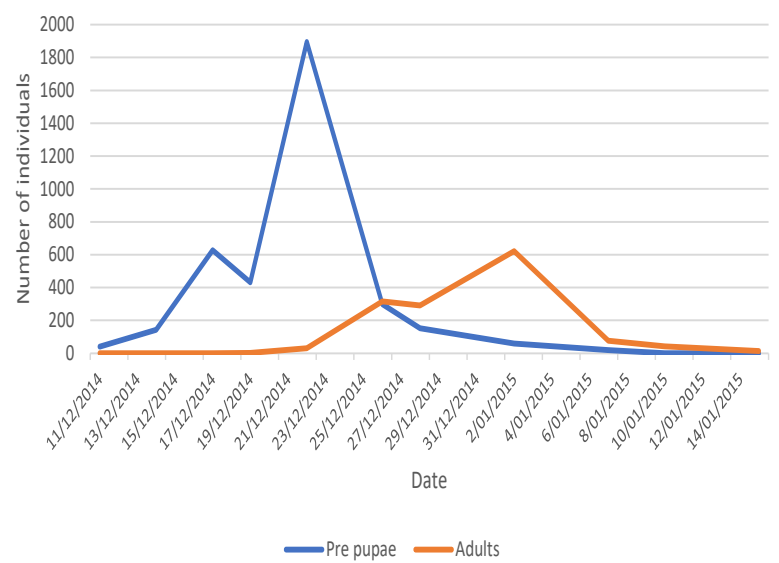

Figure 5. Number of Prodiplosis longfila Gagné pre-pupae collected on the ground and adults emerged per square meter.

Asparagus are planted in single or double rows within a drip line. Under double row crops, the insect finds the protective conditions it requires to reach the adult stage, establishing itself in the basal part of the plants and waiting for the emerging shoots to infest them and perform several cycles under similar conditions (Figure 6).

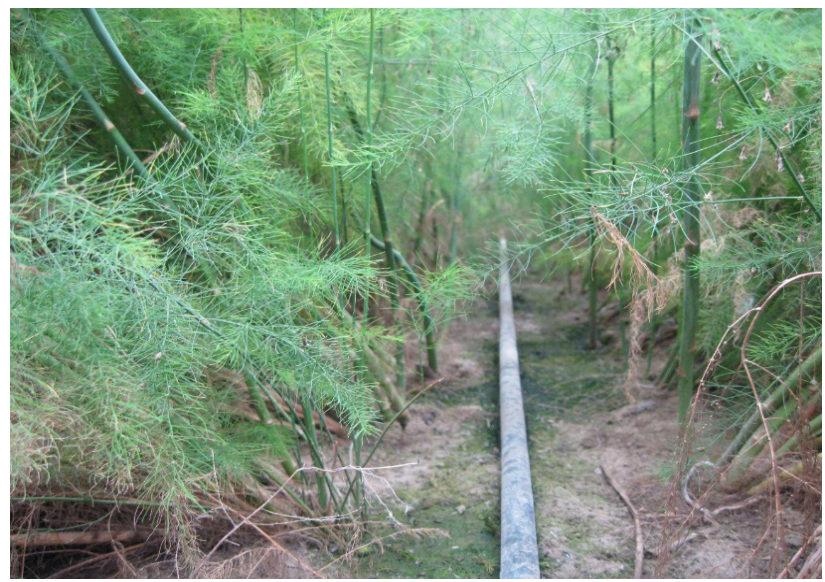

Figure 6. Double row asparagus crop with drip irrigation system between rows.

The number of larvae that may infest an asparagus spear can be few (1-10) or more $(250-400)$; however, damages in the fern are the same since they cause fern misshaping, thus causing fern deterioration lack of leaf area, and rottening (Figures 7 and 8).

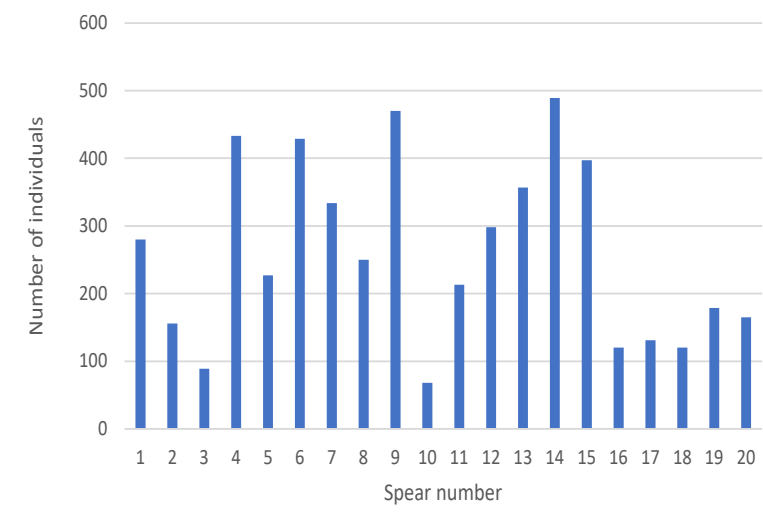

Figure 7. Average number of larvae per infested spear 


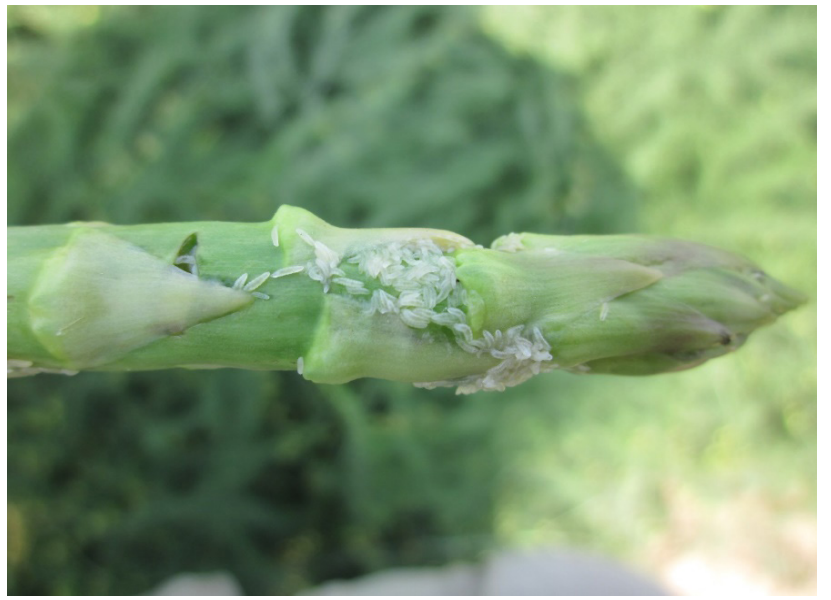

Figure 8. Asparagus spear infested by a large number of Prodiplosis larvae

In underground crown or rhizome of the asparagus plant, there are bud groups forming structures called bud clusters. These buds will either emerge to form an aerial foliage or will be harvested as a young stem or spear. Emerging buds will delay the emergence of adjacent buds in the same cluster. Removal of emerging spears during harvest reduces auxin level and growth of the next bud will consequently occur. According to Benson (1980), as the shoots emerge, reserves of the plant are depleted, producing thinner spears or shoots, and at this moment, harvest time should be completed.

Insects can also exhaust the carbohydrate reserves by destroying emerging shoots or spears, which stimulates another underground bud to form a new shoot or spear; however, if the infestation is constant or persistent, it causes exhausts the crown, thus affecting the next harvest as well as lifespan of the asparagus crop. This has been observed by evaluating the number of healthy $(32,19$, and $32)$ and affected stems $(84,56$, and 58$)$ per meter in the UC $157 \mathrm{~F} 1$ cultivar, where $29.54 \%$ of the stems were healthy, while $70.46 \%$ of the stems were affected by the insect (Figures 9 and 10).

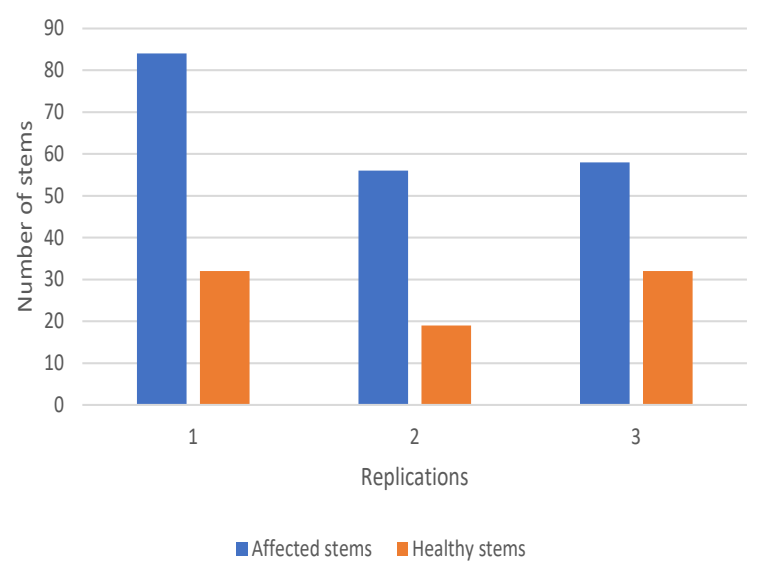

Figure 9. Number of stems infested with Prodiplosis longifila and healthy stems in the UC-157-F1 cultivar asparagus field.

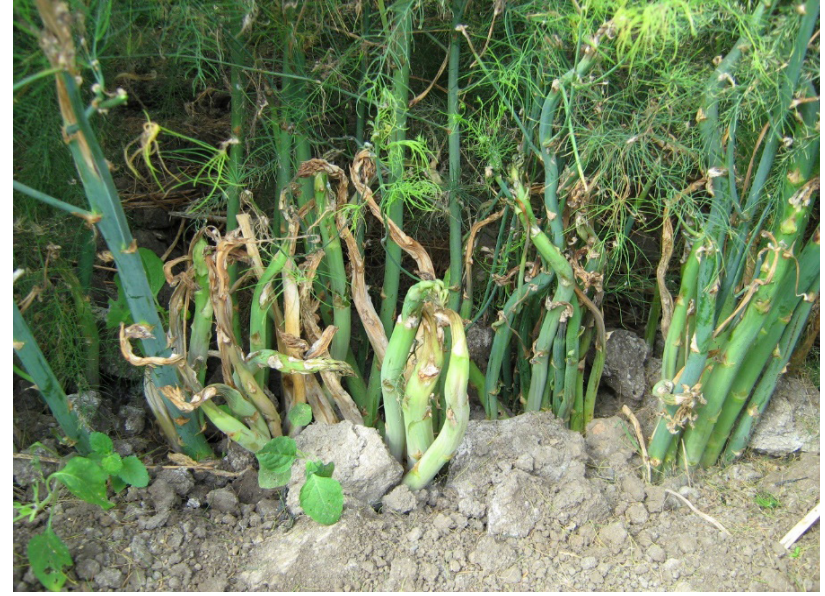

Figure 10. Number of emerging shoots infested and damaged by Prodiplosis per meter.

Infestations during flowering stage are caused by larvae that develop in male flowers, and not in female flowers. These infested flowers offer more space for development of the larvae. The proportion of male flowers infested with Prodiplosis longifila larvae can be as high as $40 \%$ and the average number of larvae per flower can be 3.7 (Prado, 2008). (Figures 11 and 12)



Figure 11. Number of larvae in male asparagus flowers



Figure 12. Number of Prodiplosis longifila larvae in male asparagus flower. 
This infestation often goes unnoticed by growers; however, the number of insects produced in this phenology stage is high, producing 34.22 pre-pupae per square meter at its peak. (Figure 13).

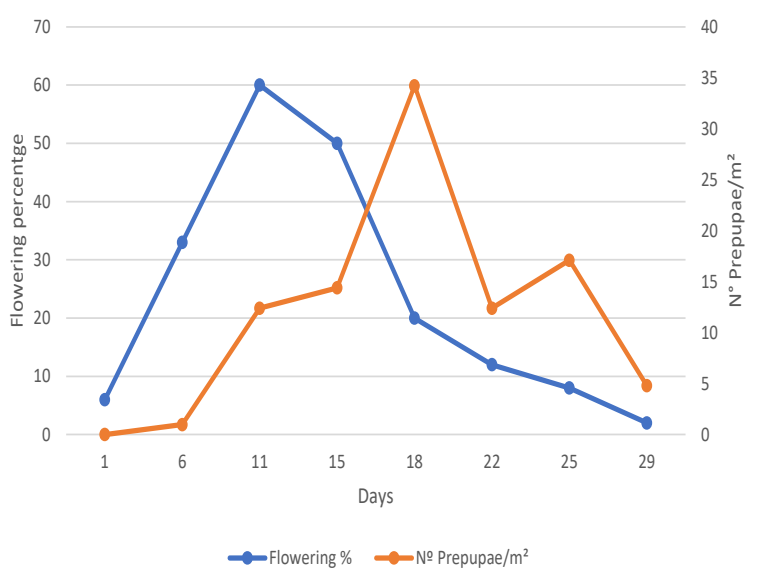

Figure 13. Flowering percentage and number of fallen Prodiplosis longifila pre-pupae per square meter.

Adults from infested fields may reinfest the same or neighboring fields. Populations that flourish from active shoots or by infested male flowers per hectare can be counted as millions, according to the crop's amount of foliage. Therefore, the success of this insect pest management is based on combination of various factors.

It was observed that as the crop develops over time the number of adults generated decreases; however, the population still remains a permanent source of infestation for the crop (Figure 14).

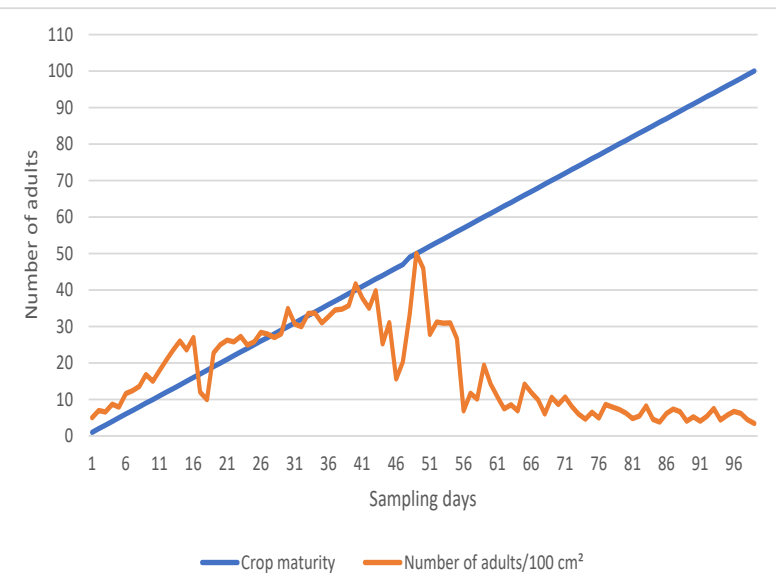

Figure 14. Number of Prodiplosis longifila adults per $100 \mathrm{~cm}^{2}$ in light traps with sticky surface panel throughout the crop phenology.

\section{Conclusions}

UC 157 is the predominant asparagus cultivar grown in the Chavimochic Irrigation Project

The agroecological conditions of the Chavimochic Irrigation Project are optimal to produce asparagus all year round, given the fact that Prodiplosis is a constant pest.
The plant morphology is favorable for the reproduction of Prodiplosis longifila since its larvae infest the bracts of emerging shoots and male flowers. The phenology most attacked by the insect is the spear emergence.

The biological cycle of the insect is approximately of 16.4 days for males and 16.7 for females.

The presence of the adult insect throughout the day increases from 10 p.m. to 4 a.m. of the next day.

May and November are the months with the highest infestations by Prodiplosis longifila .

Double row crops provide conditions for the insect to protect itself in the basal part of the plant.

The drip irrigation system maintains the soil humidity, providing optimal conditions for the insect pest pupae to survive and emerge as adult.

From the $100 \%$ puparium that fell to the ground, only $37.95 \%$ emerged as adults.

The healthy stems were $29.54 \%$ while $70.46 \%$ of the stems were affected

The number of larvae per shoot can be from 68 to 489 individuals

The number of lavas per male flower can be from 2 to 7 individuals.

There is a high relationship between flowering and the number of prepupae fallen to the ground.

As the crop develops over time the number of adults generated decreases, but still that population is a permanent source of infestation for the crop

\section{Acknowledgment}

We are very thankful to the "Crop Protection Commitee" of the Asociación de Agricultores Agroexportadores Propietarios de Terrenos de Chavimochic - APTCH" (Association of Growers, Exporters and Land Owners of Chavimochic - Crop Protection Committee) and the "Junta de Usuarios de Riego Presurizado del Distrito de Riego Moche Virú Chao" - JURP. (Pressurized Irrigation Users Board).

\section{References}

Benson, B. (1980). Asparagus Physiology. California Asparagus Seed and Transplants, Inc. Davis, California U.S.A.

Castillo, J. (2006). Prodiplosis longifila Gagné en la Irrigación Chavimochic-La Libertad. Arenagro, 2, 11-19. 
Cisneros, F. (1995). Control de plagas agrícolas. Segunda edición. 313 p.

Gagné, R. (1986). Revison of Prodiplosis (Diptera: Cecidomyiidae) with descriptions of three new species. Annals of the Entomological Society of America, 79 (1), 235-245.

Gobierno Regional La Libertad. (2010). Proyecto especial Chavimochic en cifras 2000-2010.

Hernández, L. (2014). Caracterización del daño y distribución Geográfica de Cecidomyiidae(Diptera) y sus parasitoides asociados a Solanáceas y Limón Thaiti en Colombia. [Master's Thesis, Universidad Nacional de Colombia].

Instituto Peruano del espárrago y hortalizas (2013). Consejo directivo IPEH 2011-2013.

Peña, J., Gagne, R., \& Duncan, R. (1989). Biology and characterization of Prodiplosis longfila (Diptera: Cecidomyiidae) on lime in Florida. Florida Entomologist, 72, 444-450

Prado, S. (2008). Efecto de la aplicación de fertilizantes foliares en la caida de flores del esparrago (Asparagus officinalis L.) para el manejo de Prodiplosis longifila Gagne. [Thesis, Universidad Nacional Agraria La Molina]

Rodríguez, S. (1992). Biología y morfo-taxonomía de la "caracha" (Diptera:Cecidomyiidae) en tomate (Lycopersicon sculentum Mill). c.v. Rio Grande. [Thesis, Universidad Nacional Pedro Ruiz Gallo].

Sánchez,G. \& Apaza,W. (2000). Plagas y enfermedades del espárrago en el Perú. $140 \mathrm{p}$.

Valarezo, O., Cañarte, E., Navarrete, B., \& Arias, M. (2003). Prodiplosis longifila (Diptera:Cecidomyiidae) principal plaga del tomate en Ecuador. Instituto Autónomo de Investigaciones agropecuarias. Estación experimental Portoviejo. Ecuador.

Velasco, S. (2015). Análisis de poblaciones de Prodiplosis longifila (Diptera: Cecidomyiidae) separadas altitudinalmente, mediante secuencias de ADN mitocondrial. [Doctoral dissertation, Universidad del Valle de Colombia] 